\title{
KEJADIAN KECACINGAN PADA PETUGAS PENGANGKUT SAMPAH DINAS LINGKUNGAN HIDUP DAN KEHUTANAN KOTA KENDARI
}

\author{
Nasrul $^{1)}$, Arimaswati ${ }^{2)}$, ${ }^{*}$ a Ode Alifariki ${ }^{3)}$ \\ Fakultas Kedokteran, Universitas Halu Oleo \\ Correspondence author: ners_riki@yahoo.co.id Kendari, Indonesia \\ DOI: https://doi.org/10.37012/jik.v12i1.131
}

\begin{abstract}
ABSTRAK
Infeksi cacing terjadi pada orang yang kurang memperhatikan perilaku kebersihan diri, sanitasi lingkungan rumah dan kurangnya pengetahuan tentang kecacingan. Penelitian ini bertujuan untuk mengetahui faktor-faktor yang berhubungan dengan kejadian kecacingan pada petugas pengangkut sampah Dinas Lingkungan Hidup dan Kehutanan Kota Kendari. Penelitian ini merupakan penelitian observasional analitik dengan rancangan penelitian cross sectional. Penentuan sampel dalam penelitian ini menggunakan Total sampling. Sampel dalam penelitian ini adalah 45 petugas pengangkut sampah. Pengumpulan data dengan menggunakan kuesioner dan pemeriksaan mikroskopis terhadap adanya infeksi cacing dari petugas pengangkut sampah. pada pemeriksaan sampel menunjukkan bahwa terdapat 6 responden dari 45 responden yang terinfeksi cacing. Uji statistik yang digunakan adalah chi square pada derajat kesalahan alfa 0,05.Cacing yang menginfeksi petugas pengangkut sampah adalah jenis cacing STH yaitu Ascaris lumbricoides dan Trichuris trichiura. Faktor yang berhubungan dengan kejadian kecacingan adalah pengetahuan $(\rho=0,031)$, penyediaan air bersih $(\rho=0,031)$, sarana pembuangan tinja $(\rho=$ $0,031)$, jenis tempat sampah $(\rho=0,031)$ dan jenis lantai rumah $(\rho=0,023)$. Dari Penelitian ini dapat disimpulkan bahwa pengetahuan yang baik, perilaku sehat dan sanitasi lingkungan rumah yang baik cenderung dapat mencegah kecacingan pada petugas pengangkut sampah Dinas Lingkungan Hidup dan Kehutanan Kota Kendari.
\end{abstract}

Kata kunci : Kecacingan; Pengetahuan; Sanitasi Lingkungan Rumah.

\begin{abstract}
Worm infections occur in people who pay less attention to personal hygiene behavior, sanitation of the home environment and lack of knowledge about helminthiasis. This study aims to determine the factors associated with the incidence of helminthiasis in the Kendari City Environmental and Forestry Office waste transportation officer. This study was an observational analytic study with a cross sectional study design. Determination of the sample in this study using total sampling. The sample in this study was 45 garbage transporters. Data collection using a questionnaire and microscopic examination of the presence of worm infections from garbage transport officers. examination of the sample showed that there were 6 respondents out of 45 respondents who were infected with worms. The statistical statistical test used is chi square at 0.05 alpha error. Worms that infect garbage transport workers are STH worms, Ascaris lumbricoides and Trichuris trichiura. Factors related to helminthiasis are knowledge $(\rho=0.031)$, clean water supply $(\rho=$ 0.031), faeces disposal facilities $(\rho=0.031)$, type of trash bin $(\rho=0.031)$ and type of house floor $(\rho=0.023)$. From this research it can be concluded that good knowledge, healthy behavior and good home environmental sanitation tend to prevent worms in the garbage transport officer of the Kendari City Environment and Forestry Office.
\end{abstract}

Keywords: Helminthiasis; Knowledge; Home Environmental Sanitation. 


\section{PENDAHULUAN}

Infeksi kecacingan yang disebabkan oleh soil transmitted Helminths (STH) merupakan masalah kesehatan masyarkat Indonesia. Infeksi kecacingan tergolong penyakit negleted disease yaitu infeksi yang kurang diperhatikan dan bersifat kronis tanpa menimbulkan gejala klinis yang jelas dan dampak yang ditimbulkannya baru terlihat dalam jangka panjang. Beberapa dampak yang disebabkan oleh cacing seperti kekurangan gizi, gangguan tumbuh kembang dan dan gangguan kognitif pada anak, dan apabila terjadi pada orang dewasa akan menurunkan produktivitas kerja (Darmadi et al, 2015).

Tingginya infeksi STH masih merupakan permasalahan kesehatan di berbagai daerah di dunia. Diperkirakan lebih dari dua milyar orang di dunia terinfeksi STH. Lebih dari satu milyar orang terinfeksi Ascaris lumbricoides. Tujuh ratus sembilan puluh juta orang terinfeksi Trichiuris trichiura, dan tujuh ratus empat puluh juta orang terinfeksi cacing tambang (Ancylostoma duodenale dan Necator americanus). dan Asia Tenggara merupakan salah satu wilayah yang memiliki prevalensi tinggi infeksi STH di dunia. Penelitian di daerah pedalaman Cina Selatan ditemukan prevalensi (Ascaris lumbricoides) 18,5\% pada tahun 2009 (Darmadi et al., 2015).

Di Indonesia spesies cacing yang paling banyak ditemukan secara berurutan adalah $A$ lumbricoides, T. trichiura dan N. americanus (Rusmanto, Dwi, 2012). Berdasarkan penelitian yang dilakukan di sepuluh provinsi di Indonesia ditemukan prevalensi $A$. lumbricoides 30,4\%, T. trichiura 21,2\% serta A.duodenale dan N. americanus 6,5\%. Sedangkan prevalensi pada anak-anak di tiga provinsi (Jakarta, Yogyakarta dan Sulawesi Utara) di Indonesia adalah 12,9\% untuk A. lumbricoides, 19,8\% untuk T. trichiura dan 7,8 untuk A. duodenales, dan N. americanus (Jansen et al, 2008).

Berdasarkan data yang diperoleh dari Dinas Kesehatan Provinsi Sulawesi Tenggara pada tahun 2010 prevalensi kecacingan sebanyak 29,50\%, pada tahun 2011 prevalensi kecacingan meningkat menjadi 32,11\%, sedangkan pada tahun 2012 prevalensi kecacingan turun kembali menjadi 31,08\% (Suluwi,Rezal, 2017). Untuk Kota Kendari kejadian kecacingan pada tahun 2013 sebanyak 412 orang, tahun 2014 menjadi 327 orang, pada tahun 2015 sebanyak 291 orang dan pada tahun 2016 sebanyak 256 orang (RSUD Kota Kendari, 2017). 
Faktor yang menyebabkan masih tingginya kecacingan adalah rendahnya tingkat kebersihan pribadi (perilaku hidup bersih sehat) seperti kebiasaan cuci tangan sebelum makan dan setelah buang air besar (BAB), kebersihan kuku, perilaku jajan di sembarang tempat yang kebersihannya tidak dapat dikontrol. perilaku BAB tidak di WC yang menyebabkan pencemaran tanah dan lingkungan oleh feses yang mengandung telur cacing serta ketersediaan sumber air bersih (Suluwi,Rezal, 2017).

Petugas pengangkut sampah adalah golongan pekerja yang lebih sering melakukan kontak dengan sampah dan lebih sering berada di lingkungan kotor (Maywati, 2013). Oleh karena itu petugas pengangkut sampah sangat rentan terkena penyakit-penyakit yang penularannya melalui tanah salah satunya adalah kecacingan. Kerugian langsung yang diakibatkan oleh infeksi cacing adalah dapat mempengaruhi pemasukan (intake), pencernaan (digestif), penyerapan (absorbsi), dan metabolisme makanan. Secara kumulatif, kecacingan dapat menimbulkan kekurangan zat gizi berupa kalori dan protein serta kehilangan darah. Selain dapat menghambat perkembangan fisik, kecerdasan dan produktifitas kerja, dapat menurunkan ketahanan tubuh sehingga mudah terkena penyakit lainnya (Kementrian Kesehatan RI, 2012).

Menurut penelitian yang dilakukan oleh (Maywati, 2013) tentang kontribusi penggunaan alat pelindung diri (sarung tangan) terhadap kejadian infeksi nematoda usus menunjukkan hasil dari $68 \%$ pekerja yang menggunakan sarung tangan saat bekerja terdapat $46 \%$ responden terinfeksi nematoda usus dengan jenis cacing terbanyak ditemukan adalah $A$. lumbricoides $(79,91 \%)$. Selain penggunaan alat pelindung diri, kebersihan diri juga sangat penting dalam keselamatan dan kesehatan kerja. Dalam penelitian sebelumnya yang dilakukan oleh (Mulasari, S.A. Maani, 2013) menunjukkan bahwa 8,0\% petugas sampah yang memiliki higiene yang kurang baik terdapat $0,7 \%$ yang positif kecacingan. Penelitian yang dilakukan (Sari, 2017) menunjukkan (100\%) petugas pengangkut sampah yang memiliki higiene yang kurang baik terdapat (62,5\%) positif kecacingan dan dari $100 \%$ petugas pengangkut sampah yang tidak menggunakan alat pelindung diri secara lengkap saat bekerja terdapat $25,9 \%$ positif kecacingan.

Penelitian ini bertujuan untuk mengetahui faktor-faktor yang berhubungan dengan kejadian kecacingan pada petugas pengangkut sampah Dinas Lingkungan Hidup dan Kehutanan Kota Kendari. 


\section{METODE}

Jenis penelitian ini yaitu analitik observasional dengan menggunakan rancangan penelitian cross sectional. Penelitian ini dilaksanakan pada bulan Agustus sampai September 2017 pada Dinas Kebersihan Kota Kendari. Teknik pengambilan sampel yang digunakan dalam penelitian ini adalah total sampling dengan jumlah sampel sebanyak 45 petugas pengangkut sampah yang memenuhi syarat inklusi. Pengumpulan data dengan menggunakan kuesioner dan Uji statistik yang digunakan adalah chi square pada derajat kesalahan alfa 0,05. Penelitian ini telah mendapatkan persetujuan dari Komisi Etik Penelitian Kesehatan Lembaga Penelitian dan Pengabdian pada Masyarakat Universitas Halu Oleo.

\section{HASIL DAN PEMBAHASAN}

\section{Karakteristik Responden}

Pada Tabel 1 menunjukkan bahwa karakteristik responden hanya berfokus pada dua aspek yakni usia dan tingkat pendidikan. Kelompok usia paling banyak adalah dewasa awal sebanyak 27 orang $(60,0 \%)$. Jenis pendidikan terbanyak adalah SMA atau diatasnya sebanyak 29 orang responden $(64,4 \%)$.

\section{Analisis Univariat}

Pada Tabel 1 menunjukkan hasil penelitian mengenai distribusi frekuensi komponen penelitian meliputi sanitasi lingkungan rumah (penyediaan air, sarana pembuangan tinja, kondisi tempat sampah dan jenis lantai rumah). Sebanyak 18 responden (40,0 \%) yang memiliki kondisi sarana pembuangan tinja tidak memenuhi syarat dan sebanyak 27 responden $(60,0 \%)$ yang memiliki sarana pembuangan tinja memenuhi syarat. Dari 45 responden (100\%), sebanyak 18 responden (40,0 \%) memilik kondisi tempat sampah yang tidak memenuhi syarat dan sebanyak 27 responden $(60,0 \%)$ memiliki kondisi tempat sampah yang memenuhu syarat. Dari 45 responden (100\%), sebanyak 17 responden $(37,8 \%)$ memiliki jenis lantai rumah tidak memenuhi syarat dan sebanyak 28 responden $(62,2 \%)$ memiliki jenis lantai rumah memenuhi syarat. 6 responden $(13,3 \%)$ yang positif mengalami kecacingan berdasarkan pemeriksaan feses dan 39 responden $(86,7 \%)$ yang tidak positif ditemukan telur, larva maupun cacing dewasa pada feses. 
Tabel 1. Distribusi Frekuensi Data Penelitian

\begin{tabular}{lcc}
\hline \multicolumn{1}{c}{ Karakteristik Responden } & Jumlah (n) & Persen (\%) \\
\hline Kelompok Usia & 27 & $60 \%$ \\
Dewasa Awal & 18 & $40 \%$ \\
Dewasa Lanjut & 29 & \\
\hline Status Pendidikan & 16 & $64,4 \%$ \\
Lanjut & & $35,6 \%$ \\
Dasar & 6 & $13,3 \%$ \\
\hline Kejadian Kecacingan & 39 & $86,7 \%$ \\
Positif & & \\
Negatif & 27 & $60 \%$ \\
\hline Pengetahuan & 18 & $40 \%$ \\
Baik & & \\
Kurang & 18 & $40 \%$ \\
\hline Penyediaan Air Bersih & 27 & $60 \%$ \\
Tidak Memenuhi Syarat & & \\
Memenuhi Syarat & 18 & $40,0 \%$ \\
\hline Sarana Pembuangan Tinja & 27 & $60,0 \%$ \\
Tidak Memenuhi Syarat & & \\
Memenuhi Syarat & 18 & $40,0 \%$ \\
\hline Kondisi Tempat Sampah & 27 & $60,0 \%$ \\
Tidak Memenuhi Syarat & 17 & $37,8 \%$ \\
Memenuhi Syarat & 28 & $62,2 \%$ \\
\hline Jenis Lantai Rumah & & \\
Tidak Memenuhi Syarat & & \\
Memenuhi Syarat & & \\
\hline
\end{tabular}

Sumber: Data primer, 2017

\section{Analisis Bivariat}

Hasil penelitian ini menunjukkan bahwa proporsi responden yang memiliki pengetahuan dalam kategori baik sebanyak 27 responden $(60,0 \%)$ dan mengalami positif kecacingan sebanyak 1 responden $(16,7 \%)$ dan negatif kecacingan sebanyak 26 responden $(66,7 \%)$. Sedangkan proporsi responden yang berpengetahuan kurang, yang positif mengalami kecacingan sebanyak 5 responden $(83,3 \%)$ dan yang negatif sebanyak 13 responden $(33,3 \%)$. Analisis menunjukkan bahwa nilai $\rho$ value $(0,031)<\alpha$ sehingga terdapat hubungan antara pengetahuan dengan kejadian kecacingan pada petugas pengangkut sampah Dinas Lingkungan Hidup dan Kehutanan Kota Kendari.

Proporsi responden yang penyediaan air bersih memenuhi syarat sebanyak 27 responden $(60,0 \%)$, yang mengalami positif kecacingan sebanyak 1 responden $(16,7 \%)$ dan yang negatif sebanyak 26 responden $(66,7 \%)$. Hasil uji fisher exact test diperoleh nilai p value $=0,013$. Untuk sanitasi lingkungan rumah berdasarkan kondisi sarana pembuangan tinja 
diketahui bahwa proporsi responden yang tidak memenuhi syarat ada 18 orang dan 5 positif kecacingan dan dari 27 orang yang memenuhi syarat terhadap 26 orang $(66,7 \%)$ negative kececingan. Hasil uji fisher exact test diperoleh nilai $\mathrm{p}$ value $=0,013$.

Proporsi responden dengan sanitasi lingkungan rumah berdasarkan jenis tempat sampah diketahui dari ada 18 orang tang tidak memenuhi syarat dan 5 positif kecacingan dan dari 27 yang memenuhi syarat terdapat 27 orang yang negative kecacingan. Hasil uji fisher exact test diperoleh nilai $\mathrm{p}$ value $=0,013$. Dan responden yang memiliki sanitasi lingkungan rumah berdasarkan jenis lantai rumah diketahui bahwa dari 45 responden (100 $\%)$ yang memiliki jenis lantai rumah tidak memenuhi syarat sebanyak 17 responden $(37,8$ $\%)$ dan positif kecacingan ada 5 orang $(83,3 \%)$ sedangkan proporsi responden yang memiliki luas lantai memenuhi syarat ada 28 orang dan tidak kecacingan ada 27 orang $(69,2 \%)$. Hasil uji fisher exact test diperoleh nilai $\mathrm{p}$ value $=0,023$.

Tabel 2. Analisis Kejadian Kecacingan Pada Petugas Pengangkut Sampah Dinas Lingkungan Hidup dan Kehutanan Kota Kendari

\begin{tabular}{|c|c|c|c|c|c|c|c|}
\hline \multirow{3}{*}{ Perilaku } & \multicolumn{4}{|c|}{ Kecacingan } & \multirow{2}{*}{\multicolumn{2}{|c|}{ Total }} & \multirow{3}{*}{$p_{\text {value }}$} \\
\hline & \multicolumn{2}{|c|}{ Positif } & \multicolumn{2}{|c|}{ Negatif } & & & \\
\hline & n & $\%$ & $\mathbf{n}$ & $\%$ & n & $\%$ & \\
\hline \multicolumn{8}{|l|}{ Pengetahuan } \\
\hline Baik & 1 & 16,7 & 26 & 66,7 & 27 & 60 & \multirow{2}{*}{0,031} \\
\hline Kurang & 5 & 83,3 & 13 & 33,3 & 18 & 40,0 & \\
\hline \multicolumn{8}{|l|}{ Air Bersih } \\
\hline Memenuhi syarat & 1 & 16,7 & 26 & 66,7 & 27 & 60,0 & \multirow{2}{*}{0,031} \\
\hline Tidak memenuhi syarat & 5 & 83,3 & 13 & 33,3 & 18 & 40,0 & \\
\hline \multicolumn{8}{|l|}{ Pembuangan tinja } \\
\hline Memenuhi syarat & 1 & 16,7 & 26 & 66,7 & 27 & 60,0 & \multirow{2}{*}{0,031} \\
\hline Tidak memenuhi syarat & 5 & 83,3 & 13 & 33,3 & 18 & 40,0 & \\
\hline \multicolumn{8}{|l|}{ Tempat sampah } \\
\hline Memenuhi syarat & 1 & 16,7 & 26 & 66,7 & 27 & 60,0 & \multirow{2}{*}{0,031} \\
\hline Tidak memenuhi syarat & 5 & 83,3 & 13 & 33,3 & 18 & 40,0 & \\
\hline \multicolumn{8}{|l|}{ Lantai rumah } \\
\hline Memenuhi syarat & 1 & 16,7 & 27 & 69,2 & 28 & 62,2 & \multirow{2}{*}{0,023} \\
\hline Tidak memenuhi syarat & 5 & 83,3 & 12 & 30,8 & 17 & 37,8 & \\
\hline Total & 6 & 100 & 39 & 100 & 45 & 100 & \\
\hline
\end{tabular}

Sumber: Data primer, 2017

\section{Hubungan Pengetahuan dengan Kejadian Kecacingan}

Berdasarkan dari hasil penelitian diketahui bahwa terdapat hubungan antara pengetahuan dengan kejadian kecacingan pada petugas pengangkut sampah Dinas Lingkungan Hidup dan Kehutanan Kota Kendari. Hal tersebut dilihat berdasarkan hasil yang didapat dari uji Exact Fisher Test, dimana didaptkan nilai $\rho$ Value $(0,031)<\alpha(0,05)$. Dari 18 responden 
yang memiliki pengetahuan kurang baik, terdapat 5 responden positif terinfeksi kecacingan dan 13 orang yang tidak terinfeksi kecacingan. Dan dari 27 responden yang memiliki pengetahuan baik, terdapat 1 responden yang terinfeksi kecacingan, sedangkan 26 responden lainnya tidak mengalami infeksi kecacingan.

Tingkat pengetahuan merupakan salah satu aspek yang berpengaruh terhadap tinggi rendahnya prevalensi kecacingan. Pengetahuan berhubungan dengan banyaknya informasi yang dimiliki seseorang, melalui kenyataan, melihat dan mendengar sendiri, serta melalui alat-alat komunikasi, misalnya membaca surat kabar, mendengar radio, menonton televisi dan sebagainya.

Penelitian ini sejalan dengan penelitian (Yuliani, 2007) yang berjudul Hubungan Antara Pengetahuan, Sikap dan Praktik Hidup Sehat dengan Kejadian Kecacingan Pada Siswa Sekolah Dasar Negeri Bulusan 1 Kecamatan Tembalang Kota semarang Tahun 2006, menyatakan bahwa tingginya prevalensi infeksi cacing pada anak disebabkan kurangnya pengetahuan anak dan orang tua terhadap penyakit kecacingan. hasil penelitian menunjukkan bahwa terdapat hubungan yang signifikan antara pengetahuan dengan kejadian infeksi cacing $\mathrm{p}=0,000)$, dimana nilai $\mathrm{p}<\alpha(0,05)$.

Hasil penelitian lain yang dilakukan tentang pengaruh program pemberantasan kecacingan terhadap perilaku orang tua murid Sekolah Dasar Dikelurahan Pisangan Baru Jakarta Timur menunjukkan bahwa peningkatan tingkat pengetahuan pengetahuan merupakan salah satu indikator keberhasilan program pemberantasan kecacingan (Ottay, 2010).

\section{Hubungan Penyediaan Air Bersih dengan Kejadian Kecacingan}

Berdasarkan penelitian yang telah dilakukan diketahui bahwa terdapat hubungan antara penyediaan air bersih dengan kejadian kecacingan, dimana dari 45 responden terdapat 18 responden yang mempunyai penyediaan air bersih tidak memenuhi syarat, hasilnya terdapat 5 responden yang terinfeksi cacing. Sedangkan responden yang mempunyai kondisi penyediaan air bersih memenuhi syarat sebesar 27 responden dan yang terinfeksi cacing sebesar 1 dari 27 responden tersebut. Hasil uji exact fisher didapatkan bahwa terdapat hubungan yang signifikan antara penyediaan air bersih dengan kejadian kecacingan, dengan nilai $\rho$ Value $(0,031)<\alpha(0,05)$.

Penelitian ini sejalan dengan yang menyatakan terdapat hubungan yang signifikan antara 
penyediaan air bersih dengan kejadian kecacingan pada petani sayur di Kelurahan Maharatu Kota Pekanbaru tahun 2015 (Ali, et al, 2015). Penyediaan air bersih yang tidak memenuhi syarat dapat menjadi faktor risiko yang menyebabkan terjadinya penyakit infeksi yang ditularkan melalu air dan tanah. Tanah dan air yang terkontaminasi telur cacing memiliki peranan dalam kejadian infeksi kecacingan (Yudhastuti \& D. Lusno, 2012).

\section{Hubungan Kondisi Sarana Pembuangan Tinja dengan Kejadian Kecacingan}

Berdasarkan penelitian yang telah dilakukan dapat diketahui bahwa terdapat hubungan antara kondisi sarana pembuangan tinja dengan kejadian kecacingan, dimana dari 45 responden terdapat 18 responden yang kondisi sarana pembuangan tinja tidak memenuhi syarat, hasilnya terdapat 5 responden yang terinfeksi cacing. Sedangkan responden yang kondisi sarana pembuangan tinja memenuhi syarat sebesar 27 responden dan yang terinfeksi cacing sebesar 1 dari 27 responden tersebut. Hasil uji exact fisher didapatkan bahwa terdapat hubungan yang signifikan antara kondisi sarana pembuangan tinja dengan kejadian kecacingan, dengan nilai $\rho$ Value $(0,031)<\alpha(0,05)$.

Menurut penelitian (Bundhy DA et al, 2014) penyakit infeksi kecacingan merupakan penyakit yang dipengaruhi oleh keadaan sanitasi lingkungan terutama sarana pembuangan tinja (jamban). Penyakit infeksi kecacingan ditularkan melalui soil transmitted helminthiasis sehingga pembuangan tinja akan mengurangi risiko kejadian penyakit. Pembuangan kotoran manusia bila tidak dikelola dengan baik sering mencemari air bersih sehingga air tersebut dapat menyebabkan penyakit.

Penelitian ini sejalan dengan penelitian (Surfeki G, 2017) menyatakan sanitasi dasar rumah berhubungan dengan kejadian kecacingan pada pemulung di sekitar tempat pembuangan akhir sampah $(\mathrm{p}=, 005)$.

\section{Hubungan Jenis Tempah Sampah dengan Kejadian Kecacingan}

Berdasarkan penelitian yang telah dilakukan dapat diketahui bahwa terdapat hubungan antara jenis lantai rumah dengan kejadian kecacingan, dimana dari 45 responden terdapat 17 responden yang kondisi sarana pembuangan tinja tidak memenuhi syarat, hasilnya terdapat 5 responden yang terinfeksi cacing. Sedangkan responden yang jenis lantai rumah memenuhi syarat sebesar 28 responden dan yang terinfeksi cacing sebesar 1 dari 
28 responden tersebut. Hasil uji exact fisher didapatkan bahwa terdapat hubungan yang signifikan antara kondisi sarana pembuangan tinja dengan kejadian kecacingan, dengan nilai $\rho$ Value $(0,031)<\alpha(0,05)$.

Kondisi tempat sampah yang tidak memenuhi syarat kesehatan bisa menyebabkan penyakit, salah satunya yaitu penyakit kecacingan. Tempat sampah yang tidak tertutup, tidak kedap air dan berbau sering dihinggapi serangga. Lalat merupakan salah satu serangga yang menyebabkan dan menularkan penyakit. Lalat yang selalu bersarang di sampah kotor membawa telur cacing yang sebelumnya hinggap di tanah.

Transmisi telur cacing dimulai dari telur cacing yang dibawa oleh lalat, kemudian lalat tersebut hinggap di makanan, dan makanan tersebut yang akan masuk ke dalam tubuh manusia. Sangat rawan terkena cacingan untuk anak sekolah dan balita, karena mereka yang selalu jajan disembarang tempat dan selalu bermain-main di luar rumah (Altiara, 2011).

\section{Hubungan Jenis Lantai Rumah dengan Kejadian Kecacingan}

Berdasarkan penelitian yang telah dilakukan dapat diketahui bahwa terdapat hubungan antara jenis lantai rumah dengan kejadian kecacingan, dimana dari 45 responden terdapat 17 responden yang jenis lantai rumah tidak memenuhi syarat, hasilnya terdapat 5 responden yang terinfeksi cacing. Sedangkan responden yang jenis lantai rumah memenuhi syarat sebesar 28 responden dan yang terinfeksi cacing sebesar 1 dari 28 responden tersebut. Hasil uji exact fisher didapatkan bahwa terdapat hubungan yang signifikan antara jenis lantai rumah dengan kejadian kecacingan pada petugas sampah Dinas Lingkungan Hidup dan Kehutanan Kota Kendari, dengan nilai $\rho$ Value 0,023.

Penelitian ini sejalan dengan penelitian yang dilakukan oleh (Yudhastuti \& D. Lusno, 2012) yang menyatakan bahwa terdapat hubungan yang bermakna antara jenis lantai rumah (berlantai tanah) dengan kejadian kecacingan dengan nilai OR sebesar 5,342

\section{SIMPULAN}

Pengetahuan memiliki hubungan dengan kejadian kecacingan pada petugas pengangkut sampah. Sanitasi lingkungan rumah (penyediaan air bersih, saranan pembuangan tinja, tempat sampah dan jenis lantai rumah) memiliki hubungan dengan kejadian kecacingan pada petugas pengangkut sampah. Ascaris Lumbricoides dan Trichuris trichiura adalah 
jenis cacing yang menginfeksi petugas pengangkut sampah Dinas Lingkungan Hidup Dan Kehutanan Kota Kendari. Oleh karena itu, kecederungan terjadinya kecacingan pada pekerja kebersihan akan dapat dicegah dengan meningkatkan pengetahuan tentang cara penularan cacing, perilaku hidup yang sehat serta sanitasi lingkungan rumah yang baik.

\section{REFERENSI}

1. Ali, R., Zulkarnaini, Z., \& Affandi, D. (2015). Hubungan Personal Hygiene dan Sanitasi Lingkungan dengan Angka Kejadian Kecacingan (Soil Transmitted Helminth) Pada Petani Sayur di Kelurahan Maharatu Kecamatan Marpoyan Damai Kota Pekanbaru. Dinamika Lingkungan Indonesia, 3(1), 24. https://doi.org/10.31258/dli.3.1.p.24-32

2. Altiara, S. (2011). Hubungan Sanitasi Lingkungan Rumah Dengan Kejadian Kecacingan Pada Balita di RW 03 Kelurahan Panggung Kota Tegal Tahun 2010. Universitas Negeri Semarang.

3. Bundhy DA, Kam,Sp., Rose, R. (2014). Age Related Prevalence, Intestinal, and Frequency Distribusi of Gastrointestinal Helminth In Urban Slum Children from Kuala Lumpur. Kuala Lumpur: Trans R SOC Med Hyg.

4. Darmadi, Irawati, N., \& Nasrul, E. (2015). Perbandingan Kadar IL-5 dan Jumlah Eosinofil Antara Anak dan Orang Dewasa yang Terinfeksi Ascaris Lumbricoides. Jurnal Kesehatan Andalas, 4(3), 756-764.

5. Jansen Loudwik Lalandos, D. G. R. K.(2008). Prevalensi Infeksi Cacing Usus yang Ditularkan Melalui Tanah Pada Siswa SD GMIM Lahai Roy Malalayang. MKM, 03(02), 86-91.

6. Kementrian Kesehatan RI. (2012). Pedoman Pengendalian Kecacingan. Jakarta: Direktorat Jendral PP dan PL.

7. Maywati, S. (2013). Kontribusi Penggunaan Alat pelindung Diri Terhadap Kejadian Infeksi Nematoda Usus (Studi Pada Petugas Pengangkut Sampah Di Kota Tasikmalaya). Jurnal Kesehatan Komunitas Indonesia, 9 (1).

8. Mulasari, S.A. Maani, D. (2013). Hubungan Antara Kebiasaan Penggunaan Alat Pelindung Diri dan Personal Higiene Dengan Kejadian Infeksi Kecacingan Pada Pettugas Sampah di Kota Yogyakarta. Urnal Ekologi Kesehatan, 12 (3). 
9. Ottay, R. I. (2010). Hubungan Antara Perilaku Pemulung Dengan Kejadian Penyakit Cacingan Di Pembuangan Akhir Sampah Sumompokota Manado. Jurnal Biomedik (Jbm), 2(1), 38-43.

10. RSUD Kota Kendari. (2017). Profil Rumah Sakit Kota Kendari. Kendari:RSUD Kota Kendari.

11. Rusmanto, Dwi, J. M. (2012). Hubungan Personal Higyene Siswa Sekolah Dasar dengan Kejadian Kecacingan. The Indonesian Journal of Publick Health, 8, 105-111.

12. Sari, W. . (2017). Hubungan Higiene Perorangan Dan Pemakaian Alat Pelindung Diri (APD) Dengan Kejadian Kecacingan Pada Petugas Pengangkut Sampah Dinas Kebersihan Kota Kendari Tahun 2016. Universitas Halu Oleo.

13. Suluwi, Rezal, I. (2017). Pengaruh penyuluhan dengan metode permainan edukatif sukata terhadap pengetahuan, sikap dan tindakan pencegahan penyakit cacingan pada siswa kelas iv dan v sd negeri 1 mawasangka kabupaten buton tengah tahun 2016. Jimkesmas, 2(5), 1-10.

14. Surfeki G. (2017). Hubungan Personal Hygiene, Pemakaian Alat Pelinfung diri, dan Sanitasi Dasar rumah dengan Kecacingan Pada Pemulung di Sekitar Tempat Pembuangan Akhir Sampah Parombunan Kota Sibolga Tahun 2017. Universitas Sumatera Utara.

15. Yudhastuti, R., \& D. Lusno, M. F. (2012). Kebersihan Diri dan Sanitasi Rumah pada Anak Balita dengan Kecacingan. Kesmas: National Public Health Journal, 6(4), 173. https://doi.org/10.21109/kesmas.v6i4.96

16. Yuliani, N. (2007). Hubungan Antara Pengetahuan, Sikap, dan Praktik Hidup Sehat Dengan Kejadian Cacingan Pada Siswa sekolah dasar Negeri Bulusan 1 Kecamatan Tembalang. UNNES. 